\title{
Cyberbullying Through Intellect - Related Insults
}

\author{
SHAHIDATUL MASLINA MAT SOOD \\ Universiti Malaysia Kelantan \\ TAN KIM HUA \\ BAHIYAH ABDUL HAMID \\ Universiti Kebangsaan Malaysia
}

\begin{abstract}
Unrestricted utilisation of digital devices and online platforms promulgates cyberbullying, which has been typically identified with the presence of potentially profane or offensive words that can cause aggravation to others. Previous studies have clarified that certain challenges arise in detecting abusive language in social media, especially on Twitter. The apparent reason for such encounters is typically triggered by the informal language used in various tweets. This study discusses the issues of abusive language that are used in Malaysian's online communication by highlighting the linguistic features of aggressive insulting words used by social media users in nit-picking an individual's intelligence. Data collection and analysis are conducted in two stages. Firstly, a self-constructed questionnaire is conducted to elicit imperative keywords or phrases used in assisting subsequent analysis of the content-based approach. Secondly, Twitter data, which have been streamed using the Twitter API and $\mathrm{R}$ statistical software, are explored. Thematic analysis is also used in the second phase to analyse the keywords that are subjected to qualitative explanations. Initial results indicate 'bodoh' as the most common online insult used to degrade an individual's intelligence. Twitter users also make use of more abusive words (insults) in Malay than in English for degrading purposes through a variety of intelligence-related insults such as 'bebal', 'sengal', 'gila', 'bodoh', 'bangang', 'bengap', 'semak' and 'bongok'. Likewise, linguistics realisations such as spelling alteration, word repetition, laughing remarks, punctuations, animal imagery, dialect interference, code-mixing, and Malaysian English markers are observed through the features of those highlighted insults.
\end{abstract}

Keywords: Bully, Twitter, intelligence, insults, social media.

\section{INTRODUCTION}

This study stems from an intense number of aggressive behaviours observed among social media users in Malaysia, resulting in the phenomenon of cyberbullying in the country. Indisputably, the Internet has brought various communicative advantages to its users, especially in the young generation who has expanded online services with their intense involvement on online platforms such as email, Facebook and Twitter. However, such social sites have also exposed people to various negative online effects such as insults, humiliation, hate, bullying, threats and blackmailing from close acquaintances or strangers (Rezvan et al., 2018; Hussain, Al Mahmud \& Akthar, 2018). These acts are merely conducted through undesirable image sharing, offensive remarks and messages.

Cyberbullying has received a number of terms with interconnecting connotations such as electronic bullying, cyber-aggression, Internet bullying, Internet harassment, online harassment or technology-based victimisation (Selkie, Fales \& Moreno, 2016; Korchmaros, Mitchell \& Ybarra, 2014). Cyberbullying has also been defined as an action that involves harassing and insulting an individual through hurtful messages; thus, it poses a threatening 
nature using electronic communication (Ozden \& Icellioglu, 2014; Balakrishan, 2015; Al Garadi, Varathan \& Ravana, 2016; Sari \& Camadan, 2016). Specifically, cyberbullying can be a threat to the physical and mental health of victims (Nandhini \& Sheeba, 2015). In previous studies, cyberbullying is considered an extension of traditional bullying with the exception of its execution, which is primarily accomplished through online chats, online media, and short messaging texts. Given that cyberbullying is being deliberated as a type of covert bullying with faceless bullies (Lai et al., 2016) attacking their victims in a covert manner, it tolerates the rapid dissemination of information and provides convenient accessibility for bullies to conduct bullying without temporal and spatial restrictions (Guan et al., 2016). Hence, anonymity and convenient accessibility are partially accountable for the act of cyberbullying, given that they render an environment that incites people to conduct aggressive behaviours through virtual interaction.

Cyberbullying can cause more damage than traditional bullying, given that victims' humiliation can 'go viral' and become publicly known to others in a short period. Unlike the victims who have been bullied in the conventional way, in which such victims would receive some reprieve whenever they are out of their aggressors' reach, the victims of cyberbullying can be attacked at all times (Miller, 2016). Due to the virtual nature of cyber activities, cyberbullying victims may not perceive the bullying activity as serious, whereas others may feel hopelessness given that they have nowhere to hide or run. In the case of Malaysians, cyberbullying is considered a 'silent epidemic' (Abu Bakar, 2015), given that it is one of the most detrimental effects of Internet jeopardies that social media users normally suffer.

\section{LITERATURE REVIEW}

\section{Cyberbullying in Malaysia}

The risks of Internet abuse in Malaysia including cyberbullying become increasingly prominent, given the rise of Internet usage in the country. Recent statistics show that Malaysia has approximately 20.1 million active Internet users, with 16.8 million active social media accounts (LiveatPC.com, 2019). Cyberbullying has attracted attention when a survey conducted among 28 countries showed that Malaysia is sixth in the global cyberbullying rankings and second among Asian countries after India (Rosli, 2018). However, cyberbullying is not a novel subject in Malaysia due to the cases being reported over the years. Specifically, a total of 34 suicide cases are reported in less than ten years involving teenagers (below 18 years) and have been linked to cyberbullying (Abu Bakar, 2015). Moreover, 37\% of Malaysian youth claim to have encountered and experienced cyberbullying (Telenorgroup, 2016). Although the reports have been handled as isolated incidents, cyberbullying rates in the country are far from decreasing.

The latest news updates also underline numerous cyberbullying cases that target everyone, regardless of their gender, race, religion, age, and background. In one case, a video of a woman known as Kiki who was verbally assaulting a 68-year-old man after a car accident went viral, and the situation worsened when some went overboard by revealing her personal details on the social media. Kiki was bashed and received ruthless criticisms for weeks from netizens due to her actions (Syafique, 2014). An actor, Hafidz Roshdi, also became a victim of cyberbullying in 2016 when some tactless netizens left offensive and mean online comments on his wife's appearance (Agency, 2017). In contrast to Hafidz, who was cool in reading the netizens' comments, a 16-year-old Malaysian skateboarder was forced to delete her Instagram account, leaving an apology note saying, 'Sorry, Malaysia' after placing last in a competition. She removed her account because she felt extremely pressured by the 
comments (Malaymail, 2018) that turned hysterical. The same thing happened to Arlina Arshad (also known as Arlina Banana, a writer and online personality). She received cruel insults regarding her physical appearance, and as a result, such endless nasty comments led her to shut down her Twitter account (Tang, 2016). Additionally, a case in Penang also became viral, given that a 20-year-old college student committed suicide due to cyberbullying (Brown, 2017). All of these cases are definitely distressing to the society, thus leading local researchers to start turning their focus to cyberbullying and its other nuances.

Among local studies, Yusuf, Hassan and Ibrahim (2018) stated that reports and findings (with non-empirical findings) that are linked to cyberbullying in Malaysia are abundant. Similar to international researchers, scholars in Malaysia have conducted studies related to cyberbullying issues. However, most of these studies were conducted by discussing cyberbullying superficially. Specifically, such studies focused on the prevalence, causes, effects and preventions, typically involving children and teenagers. Thus, the findings of these studies were quantitatively oriented. Among those studies are Ang and Goh (2010), Chasib (2014), Noh and Ibrahim (2014), Balakrishnan (2015), Asanan, Hussain, and Laidey (2017), and Yusuf et al., (2018). However, Ghani and Ghazali (2015) asserted that cyberbullying studies conducted using the qualitative approach are lacking in Malaysia. Accordingly, they decided to examine the youth's perception of cyberbullying by employing focus group discussions as the data collection method. Similarly, Simon (2017) adopted a qualitative approach in her study on the school experience of eight cyberbullied victims using a semi-structured questionnaire technique.

\section{Problem Statement}

Cyberbullying is one of the negative influences that often associated and resulted from an increase in the use of offensive language in social conversations. In relation to this definition, societal concern on cyberbullying has grown in Malaysia due to distressing findings. For example, two-thirds of Malaysian youth feel that the action of sending offensive messages, posting appropriate photos and pretending to be someone else is not considered as 'cyberbullying' (Telenorgroup, 2016). Moreover, in a survey conducted by PeopleACT, 400 Malaysians stated that the most common form of cyberbullying is hateful comments (Brown, 2017). These findings convey worries to the society, given that Malaysian are sentient enough to know that the advancement of the Internet and its technologies essentially offers an infinite space for its users (especially the young generations) to explore with fewer restrictions, bringing opportunities to humiliate, bully or harass others online (Yusuf, Hassan \& Ibrahim (2018). Owing to the anonymous nature of the assault (Lai et al., 2016), cyberbullying has the potential to generate more side effects than 'real-life bullying', making the issue more intricate and strenuous to address. Studies also examined the effects of cyberbullying on its victims, bullies and bully-victims (Guan et al., 2016). Cyberbullying has been proven to be strongly related to suicidal ideation, suicide attempts, serious depression and stress (Kowalski et al., 2014, Gan et al., 2014; Van Geel, Vedder \& Tanilon, 2014).

Looking at the severity of cyberbullying impact, the society should be aware that cyberbullying does not merely affect victims, but it can also negatively involve bullies and witnesses (also known as bystanders). Although this study takes the initiative to understand cyberbullying behaviours in all parties, it also focuses on the main cause of cyberbullying. In this case, this study returns to the aggressive acts done by social media users through their use of abusive language on online comments and other social media posts. Such language has 
become fairly common in online communication, particularly in the conversation of young people. However, some may not even be conscious of the linguistics realisations and the acute unpleasantness of those insulting words. Thus, this study pinpoints the linguistic features of intelligence-related insults with the hope that it can make a small contribution in combating cyberbullying incidences in the country and expose the society to the domain of polite discourse in online communication.

\section{Conceptual Framework}

To achieve the research objectives of this study, the underpinning theory was derived from the five categories of abusive language as proposed by Rezvan et al. (2018). These five categories are sexual, racial, appearance-related, intellectual and political harassments, as shown in Table 1.

Table 1: Typology of abusive language (Rezvan et al., 2018)

\begin{tabular}{ll}
\hline Sexual harassment & It normally affects sexuality and often aims at females. The harasser might \\
denote a victim's sex organs with slang or depict sexual relations with slang. \\
It directs victim's race and ethnicity qualities such as colour, country, \\
culture, faith and religion. \\
Appearance-related & It is associated with body appearances such as hair style and looks. Fat \\
harassment & shaming and body shaming are among its disparaging subtypes. \\
Intellectual harassment & It involves intellectual power or the merits of a person's judgment. Level of \\
formal education and grammar are among its varieties. However, the \\
victims may in fact be intellectually gifted. \\
It concerns political views, and typical victims are mostly politicians and \\
politically active individuals.
\end{tabular}

In this study, the collected tweets were grouped based on the abovementioned categories. However, only the keywords or phrases under the 'Intellectual Harassment' category were further analysed. Given the urgent need to recognise and comprehend the linguistic features of abusive words (insults), another framework from Ibrohim and Budi (2018) was adopted and used as the parameter for additional evaluation. Among the features that govern Indonesians' writing patterns in social media are the use of informal forms (abusive words), foreign and local languages and character repetition and substitution. However, this study has identified additional linguistics realisations for the intelligencerelated insults used in Malaysians' social media platforms.

\section{METHODOLOGY}

This study uses a qualitative approach in which a combination of a survey questionnaire and Twitter data has been explored in achieving research objectives. A qualitative approach is selected, given that it normally provides an in-depth perspective, including the linguistic features for intelligence-related insults in this study.

\section{Intelligence-Related Insults Questionnaire}

\section{a. Questionnaire Construction}

Given that the researchers could not find any survey design on the linguistics features relating to cyberbullying words and phrases, a newly designed questionnaire was constructed to elicit keywords of phrases that are commonly used on social media. Keywords obtained from the questionnaires were used as a stimulus in pulling out selective keywords, together with their contexts from real-time data (Twitter) for further analysis. The questionnaire (see Appendix) 
is composed of 18 items divided into three sections. In Section 1, the respondents were given options for demographic information. Section 2 addresses respondents' experiences as victims (Questions 3-7), involvement as bullies (Questions 8-11) and experiences as witnesses (Questions 12-14). Questions 15-18 require respondents to write and rank insulting words or phrases based on their perception of its degree of harmfulness. The questionnaire was conducted in two stages: data collection and analysis.

\section{b. Data Collection}

\section{(i) Sampling Procedure}

A convenience sampling approach was used in distributing the questionnaire to 125 tertiarylevel Malaysian youth in Universiti Kebangsaan Malaysia with the ages ranging from 18-26 years old. The sample selection was made based on the availability and representativeness of Malaysian youth, regardless of their gender, age and race.

\section{(ii) Questionnaire Distribution}

The questionnaires were distributed on March 21, 2019 to 125 undergraduate students of a public university in Malaysia. The distribution of the questionnaires was conducted in a selected lecture hall, with prior consent obtained from respective lecturers and students. To attain the most genuine response that reflects social reality, none of the respondents had prior knowledge of the protocol. A total of 15 minutes was allocated for the respondents to complete the questionnaires to avoid them from overthinking, copying or sharing one another's responses. Once completed, the questionnaires were handed over to the researchers.

\section{c. Data Analysis}

The completed questionnaires were given a numbering label from 1 to 125 to avoid repetition and confusion in keying-in the data. Once labeled, the responses were keyed-in and tabulated using SPSS Statistics 23. Questions 1-3 were keyed-in following a numeric type and given values of 1 and 2 . Given that they were considered relatively insignificant towards the research objectives, the first three questions were merely analysed using frequencies. Questions 4-10 (excluding Question 8) were given more emphasis and they were keyed-in following a string type. Unanswered questions were left empty in the space. All responses from Questions 4 to 10 (excluding Question 8) were copied and transferred into Microsoft Excel for manual-coding analysis. Using Excel, the words and phrases with similar connotations to intellect abuse were distinguished, manually coded and placed under one category called 'INTELLECT ABUSE'. The selection of keywords was conducted based on descriptions given by Rezvan et al. (2018). These keywords were later used as a stimulus in pulling out selected Twitter data for further language analysis in relation to its forms and functions of real-life online communication.

\section{Data Extraction from Twitter}

\section{a. $\quad$ Twitter Data Streaming}

Weekly data from Twitter were streamed within the period of 18-25 April 2018 using Twitter's API and R statistical software. To ensure the validity of the research and achieve its objectives, some requirements were set before the streaming process. Tweets were filtered based on location, account status and language of instructions as follows: 
(i) Tweets were geologically limited to Malaysia,

(iii) Tweets were collected from active accounts and

(iv) Tweets only used English and Malay languages as the mediums.

Through the process of filtering, box coordinates were used in differentiating local tweets and those from neighbouring countries (such as Indonesia, Brunei, Thailand, Singapore and the Philippines). The accounts that are active (as opposed to the idle ones, these accounts also set their geo-location available to public) and those who were identified as using English and Malay languages as the mediums were simultaneously filtered. As a result, approximately 427,108 tweets (from 42,312 Twitter users) in various lengths and themes were accumulated.

\section{b. Data Analysis}

A total of 427,108 streamed tweets were transferred into Microsoft Excel Comma Separate Values Files for further annotation conducted in four stages:

(i) Stage 1: Screening tweets using pulling words

The researchers screened the $427 \mathrm{~K}$ tweets by using pulling words (keywords gathered earlier from questionnaires) individually. In addition to manual searching, the 'Find' tab was also utilised by keying-in the keyword into search entry to look for related tweets that contain that particular keyword.

(ii) Stage 2: Coding and labelling tweets manually

Selected tweets from Stage 1 were copied into another sheet in which manual coding and labeling were completed. In this stage, the researchers colour-coded the tweets and put a label next to it. The labels were used to put them under categories in Stage 3.

(iii) Stage 3: Categorising obtained tweets

Each of the colour-coded and labelled tweets was rescreened. The same tweets with similar keywords were put under one category using the approach of Rezvan et al. (2018).

(iv) Stage 4: Analysing categorized tweets

Categorised tweets were analysed based on the needs of this research. The focus was given to the forms and functions of intelligence-related insults, which were further analysed using Indonesians' social media writing patterns introduced by Ibrohim and Budi (2018).

\section{RESULTS AND DISCUSSION}

The findings are discussed under two sections that correspond to the research objectives. The first part emphasises the findings of commonly used intelligence-related insults that are elicited from the questionnaires and Twitter. The second part of the findings addresses explicit results by drawing attention to the linguistic features of intelligence-related insults as found in tweets.

\section{Commonly Used Words for Intelligence-Related Insults}

Results from the survey questionnaire showed numerous abusive words used by social media users. The results listed several keywords for intelligence-related insults such as stupid, uneducated idiot, nerd, noob, stupid asshole, nub, too stupid dumb, dumb ass, uncultured swine and a Malay word, 'bodoh'. 
With the help of these keywords as pulling words, a list of abusive words that are used in harassing someone's intellect was also gathered from Twitter analysis. Twitter users use more Malay abusive words in mocking someone's intelligence than English words. Other recurring words such as 'bebal', 'sengal', 'gila', 'bodoh', 'bangang', 'bengap', 'semak' and 'bongok' have similar connotations for insulting someone's intelligence, and they become apparent in most cases in which a strong insulting remark is intended to a person. Some other occurrences of phrases like 'perangai tak matang', 'kurang akal', 'jenis acah-acah taw semua', 'takde otak', 'sila guna otak', 'kepala bana' and 'tak matang' are being used for the same purpose, but with fewer occurrences in the tweets. The twitter analysis also disclosed several English abusive words that are used in online communication to mock someone's intelligence. Corresponding with pulling words from questionnaires, some manifestations of words, such as bimbo, stupid, dumb, nerd, noob, idiot and arrogant, are found in tweets. For further analysis, 'bodoh' ('stupid' in English) was chosen by the researchers, given that it has the most incidences in Twitter and thus provides ample data for the second phase of analysis.

\section{Linguistic Features of Intelligence-Related Insults}

Although stupid is labeled as an abusive word used in insulting someone's intelligence among native speakers of English, the findings reveal that Malaysians predominantly use 'bodoh' in most occasions to portray their annoyance and anger. MyKamus English Malay-Malay English Online Dictionaries defined 'bodoh' as 'not clever and stupid'. In most cases wherein the term is used, 'bodoh' is considered a taboo term among Malaysians (specifically the Malays), given that it can challenge someone's sensitivity if the word is used on them. In describing the linguistic features of intellect-related insults, the researchers decided to use findings on 'bodoh' as the foundation, given that it subjugated the number of occurrences in the tweets.

\section{a. Bodoh as Prominent Abusive Word}

'Bodoh', a Malay word used to denote stupidity, is substantially registered in the analysis. This term has been literally defined by Dewan Bahasa dan Pustaka in Kamus Pelajar Edisi Kedua as 'tidak mudah mengerti ketika mempelajari sesuatu; tidak pandai'. In terms of its linguistic features, 'bodoh' can stand alone, or it can be part of two or more than three words.

(i) 'Bodoh' in One Word

Malaysians perceive 'bodoh' as a vulgar word. However, regardless of how heartless and unpleasant the word is to a person, the use of 'bodoh' has the highest weight in the analysis.

Table 2: Bodoh in one word

\begin{tabular}{|c|c|}
\hline Post no. & Tweet \\
\hline \#293 & $\begin{array}{l}\text { 'Ei geram je ak nk maki kan bdk ni. Ko nk balik kg blik jela nk election ke ape. Tye bahaya } \\
\text { ke } x \text {, bodoh ke. Hakalaa. Kau ctdk ke org nk tgk'? }\end{array}$ \\
\hline \#3577 & 'Moody teruk lah bodoh tidur kena kacau punya pasal eeeeeeeee' \\
\hline \#3753 & $\begin{array}{l}\text { 'Susah betul lah manusia ni. Nampak orang diet, disuruh makan. Bila nampak orang } \\
\text { makan disuruhnya diet. Bodoh janganâ }\left.\right|_{1} ^{\prime} \text { https://t.co/Sa1KF71ujd' }\end{array}$ \\
\hline \#3812 & 'Kalau nak tahu annnnn. Aku takdelah bodoh mana ð̈̈ Ž. Hehehehhehee' \\
\hline \#4654 & 'sudah sudahlah tu jadi jantan tak guna buat malu kaum lah kau ada rupa tapi bodoh'. \\
\hline
\end{tabular}


'Bodoh' alone is considered a rude word. However, the level of offensiveness of the word is deliberated as less offensive and vulgar compared with other 'bodoh' words that have been connoted with two words or more, as elaborated in the subsequent section.

(ii) 'Bodoh' in two words

Few occurrences of 'bodoh' in two words were found in the analysis. These two words are normally adjectival phrases in which 'bodoh' has been associated with some adjectives to provide meaning and emphasis. Some examples that use 'bodoh' in two words are given below.

Table 3: Bodoh in two word

\begin{tabular}{|c|c|}
\hline Post no. & Tweet \\
\hline \#2246 & 'Ikr! Bodoh abadi ah yg reply ni pikir kelakar la tu haih' https://t.co/iCeeiH4nD5 \\
\hline \#2405 & Bodoh betul \\
\hline \#3493 & 'Bukan stress sbb banyak kerja tau tapi stress bila kena deal dgn orang bodoh'. \\
\hline \#4504 & $\begin{array}{l}\text { '@BBSemasa Kalau kpop bodoh tu yg bunuh diri ni dah meraung raung dah yg komen } \\
\text { buat lawak bodoh ni' }\end{array}$ \\
\hline \#4751 & $\begin{array}{l}\text { 'Dah letak instructions pun masih bodoh tak mau ikut. Tak kisah la kau tua ke muda ke. } \\
\text { Memudahkan kerja orang kan leâ€! https://t.co/D16hd58PrC' }\end{array}$ \\
\hline \#9095 & $\begin{array}{l}\text { 'ade jugak dak twt yg komen menganjing depression.. Ingat kat fb je golongan bodoh } \\
m \mathrm{~mm} n i \ddot{\mathrm{Y}}^{\mathrm{TM}} \text { ", https://t.co/aFFv3io9vZ' }\end{array}$ \\
\hline
\end{tabular}

Tweets \#2246 and \#2405 are the examples of how 'bodoh' is combined with adjectives to put more weight on the word, syntactically known as 'adjectival phrases'. In \#2246, the word 'bodoh' is linked with an adjective 'abadi'. Malay Oxford Living Dictionaries defines 'abadi' as 'endless, without end, continual, existing always, unchanging, eternal, living forever, not mortal, famous for all time and immortal'. In this tweet, 'bodoh abadi' refers to endless stupidity. This term is perceived as a negative expression that can be hurtful to people, given that its impact is doubled when it is measured up to the word 'bodoh' alone. Other derivatives that have identical features are 'bodo nokrom' and 'bodo gemuk'. The same finding can be applied to $\# 2405$, given that 'betul' is used as an adjective to modify the meaning of 'bodoh'. 'Bodoh betul' when translated to English means 'real stupidity' and the word 'betul' accentuates the connotation of stupidity and sounds more insulting, similar to \#4751 'masih bodoh' (still stupid). However, 'masih' is an adverb of degree that signifies the meaning of still, then or now as before and nevertheless, according to Malay Oxford Living Dictionaries. In this case, the use of the adverb 'masih' in the tweet indicates a degree of the adjective ('bodoh').

(iii) 'Bodoh' in More Than Three Words

Another feature is 'bodoh' in more than three words. Although this feature is not evident in the analysis, it still has some importance and worth to be discussed due to its characteristics. Examples of such words are given below.

Table 4: Bodoh in more than three words

\begin{tabular}{|c|c|}
\hline Post no. & Tweet \\
\hline \#2731 & $\begin{array}{l}\text { 'Kebiasaannya yg bercakap bagi pihak Kerajaan BN akn membiarkan mereka dan } \\
\text { keluarganya dlm KEBODOHAN yg abadiâ€' https://t.co/uGO8Q4YNRN' }\end{array}$ \\
\hline \#5515 & 'Pakwe bodo..makwe dua kali ganda bodo sbb diperbodohkan hahah aduh kasihan' \\
\hline
\end{tabular}


Tweet \#2731 highlights 'bodoh' in more than three words with the phrase of 'KEBODOHAN yg (yang) abadi', whereas 'dua kali ganda bodo' is used in \#5515. In \#2731, the adjective 'bodoh' is nominalised to be a Malay noun 'kebodohan', and the word itself has been capitalised to denote its prominence. The emphasis of 'bodoh' or 'bodo' in \#5515 is emphasised with the phrase of 'dua kali ganda'. In this case, 'dua kali ganda' refers to the level of stupidity that is amplified.

b. Spelling Alteration/Variation/Modification

The results indicate that the word 'bodoh' also has other equivalents but with spelling variations, such as 'bodo', 'buduh' and 'budus', all of which serve the same connotation. Some examples are listed below.

Table 5: Bodoh using other spelling alteration/ variation/ modification

\begin{tabular}{|c|c|}
\hline Post no. & Tweet \\
\hline \#1073 & 'Sehari kalau takbodo mmg tak boleh' \\
\hline \#1595 & 'Bodo apa class hari jaat 4.30-6'? \\
\hline \#2560 & 'Bodo la gi basuh lens guna micellar water' \\
\hline \#3033 & 'bodo screen retak fak fak fak' \\
\hline \#703 & 'stress lah hari2 byk call. Buduh' \\
\hline \#6384 & 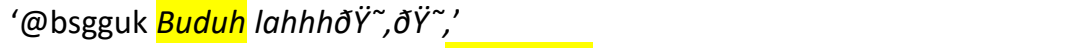 \\
\hline \#3262 & '@shamshafiq Hahahahahaha buduuusss. Sedap do tengok aiskrim dia clrfl' \\
\hline
\end{tabular}

\section{c. Repetition of individual letters of a word}

Repetition of individual letters of a word is one of the linguistic features that might contribute to the spelling variation of a word. In the case of the abusive word 'bodoh', the word itself experienced spelling variations with repetition of individual letters of a word. 'Bodoh' is spelled as 'buduuusss' in \#3262 with the repetition of the vowel ' $u$ ' and the consonant ' $s$ '. Budus is a term coined by Malaysians to tone down the word 'bodoh' to make it more palatable. However, despite this purpose, the additional vowel and consonant signals another level of irritation and frustration of the speaker. Post \#6697 below shows another individual letters repetition in the analysis.

Table 6: Bodoh in spelling variations

\begin{tabular}{cc}
\hline Post no & Tweet \\
\hline$\# 3262$ & '@shamshafiq Hahahahahaha buduuusss. Sedap do tengok aiskrim dia clrfl' \\
$\# 6697$ & 'Serabut la speaker ni bodooooooooooooo' \\
\hline
\end{tabular}

In \#6697, the repetition and elongation of the vowel 'o' reflects the level of the speaker's infuriation towards the subject. In this case, the longer the elongation, the more that the speaker is upset.

\section{d. Punctuation Use}

Exclamation marks are normally used to show raging emotions of anger, as proven in tweets \#3522 and \#8136. These tweets show the speakers' sentiments of being infuriated with something out of their control. 
Table 7: Bodoh with punctuation mark

\begin{tabular}{cl}
\hline Post no & \multicolumn{1}{c}{ Tweet } \\
\hline \#3522 & 'Bodoh! Patut la takde org nk halang pun kau nk resign. Dah la guna resignation utk \\
& blackmail naik gaji. Pastu jealoâ€' https://t.co/c1pFcc1a6V' \\
$\# 8136$ & 'Banyak benda aku nak pikir lah dari benda bodo ni'! \\
$\# 1595$ & 'Bodo apa class hari jaat 4.30-6'? \\
\hline
\end{tabular}

In addition to exclamation marks, question marks are also used together with the abusive word 'bodoh'. In tweet $\# 1595$, the question mark is used to question the situation that is perceived by the speaker as nonsensical and ridiculous, whereas the phrase 'bodo apa' reflects the speaker's exasperation with the situation.

\section{e. $\quad$ Code-Mixing and Code-Switching}

Another linguistic feature that has been identified through the use of intelligence-related insults is the use of code-mixing. The immense practice of code-mixing and code-switching (from English to Malay and vice versa) among social media users has been identified in the analysis. Code-mixing is used interchangeably with code-switching in the literature, and they serve different purposes for pragmatic reasons. Findings reveal that intra- and intersentential switching are highly exploited in Malaysian tweets that enclose intelligence-related insults due to the quite distinctive nature of the two. The analysis reveals an irregular manifestation of a combination of two words from different languages (that have similar connotations) being blended together. In tweet \#29494, Malay and English words that have the same connotation ('bodoh' and stupid) are being intermixed. The speaker's intention in mixing up both languages is to point out the highest degree of stupidity (directed to the audience). The same thought process may be applied to \#4659, in which a code-mixing of 'fak' (fuck) is combined with 'bodoh'. In this particular tweet, intersentential switching was used.

Table 8: Bodoh combining Malay or English curses

\begin{tabular}{cl}
\hline Post no. & Tweet \\
\hline \#29494 & 'bodoh stupid' \\
$\# 3033$ & 'bodo screen retak fak fak fak' \\
$\# 4659$ & 'Nak buat keje selalu tak kene time fak bodoh' \\
\hline
\end{tabular}

Tweet \#3033 also uses code-mixing. However, the aggravation of 'bodo' is negatively intensified with the vulgar slang 'fak fak fak' (formally written as 'fuck fuck fuck'). The spelling of the word 'fuck' itself is modified by social media users into 'fak'. In sum, Malaysians are likely to use code-mixing or code-switching in their online communication to fit several reasons emphasised by Crystal (1987) and Maros et al. (2016). Specifically, conveying their attitude to the audience and creating rapport and social bonding among online users. In discussing social factors that may drive Malaysians to switch or mix codes, Hadei, Kumar and Jie (2016) listed 10 motives for code-switching in Malaysian society. These motives include showing of identity within a group, addressing different audiences, lacking of facility (inability to find suitable vocabulary), utilising pragmatic reasons (to call attention to the context of a conversation), lacking of registral competence (certain vocabulary is not available to a speaker in the first language [L1]), exploring semantic significance (to signal the speaker's attitude, communicative intentions and emotions to convey linguistic and social information), to attract attention and habitual expressions (to amplify and emphasise the point and mood of the speaker). 
f. Use of Malaysian English Emphasis Markers

In relation to the code-mixing among Malaysian social media users, the habit of using Malaysian English emphasis markers is relatively perceptible in their online conversations. The use of ' $l a h$ ' and ' $l a$ ' has been pinpointed in the analysis, given that they are mutually used with the abusive word 'bodoh' as shown below.

Table 9: Bodoh using Malaysian English emphasis markers

\begin{tabular}{|c|c|}
\hline Post no. & Tweet \\
\hline \#4168 & $\begin{array}{l}\text { 'Bodohlah ada orang guna beli tiket bus online gi KL laktu dari mana pun aku tatau benda } \\
\text { do' }\end{array}$ \\
\hline$\# 6720$ & $\begin{array}{l}\text { ‘Azmanlbrahim_@Sharihannnn @theadami @symmirilhm @iamFirdausjamil @jejulll } \\
\text { Bodolah man hashtag hahahahahah' }\end{array}$ \\
\hline \#6384 & 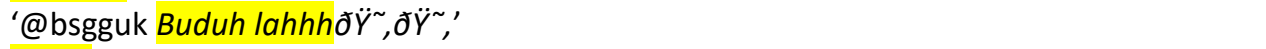 \\
\hline$\# 2560$ & 'Bodo la gi basuh lens guna micellar water' \\
\hline \#7772 & 'Bodo la anep ni uahahahahahahahahahahahahaha' \\
\hline
\end{tabular}

Regardless of the spelling variations of 'bodoh' such as in \#4168, \#6384 and \#2560, ' $I a^{\prime}$ and ' $l a h^{\prime}$ ' are used with the intention to put an intense sentiment to the word 'bodoh'. Lee (2015) added that the manner and the tone used in speaking can indicate a distinct meaning to a word or sentence, and it can be used to show confidence, appease a person and reflect anger. The analysis indicates that the two markers, ' $l a h^{\prime}$ and ' $l a$ ', are used to emphasise a word and signal irritation. However, ' $l a h^{\prime}$ ' sounds provocative and harsh to the audience (especially to the person to which it is directed), whereas ' $l a$ ' is deemed less stimulating and subtle.

\section{Other Linguistics Features of Intelligence-Related Insults}

a. Dialect Interference

Findings from other intelligence-related insults also showed few incidences of code-mixing and code-switching when it involves regional dialect interference. This situation was referred to by Don (2003) as 'dialect code-switching'. Given that Malaysia is known as a multilingual and multidialectal country, Malaysian speakers consistently choose among different languages to use when they are communicating with people of other races and those from distinct dialect areas. The options they select typically reflect a message beyond the referential meaning of a statement. The analysis disclosed numerous tweets that used this dialect code-switching approach when harassing someone online. Some examples are given below.

Table 10: Bodoh in spelling variations

\begin{tabular}{|c|c|}
\hline Post no. & Tweet \\
\hline \#1345 & ‘@famkahphin Muka kau tua bahhh. Noob’ \\
\hline \#11866 & 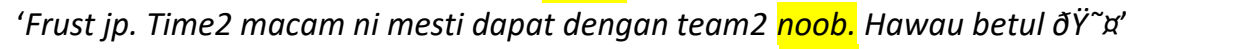 \\
\hline \#20944 & '@onecthegreat Nda menahan sda ni team party tapi noob' \\
\hline \#22532 & 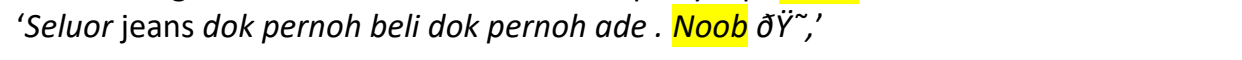 \\
\hline \#35004 & $\begin{array}{l}\text { 'Padiaaaaa si rock ni. Hg kalau buat kerja leklok org tak kacau aih. Ni waktu kerja } \\
\text { melangut drkat kantin. Noob' }\end{array}$ \\
\hline \#40647 & $\begin{array}{l}\text { '@KJoibi Noob pasang bus kan, tu lovren la punca, suda tau pindik mau juga lumpat, } \\
\text { useless trus kna gol 1st' }\end{array}$ \\
\hline \#31968 & 'Noob siak main tweeter nie.. baru lagi..' \\
\hline
\end{tabular}


In tweet \#1345, an emphasiser ' $b a h^{\prime}$ ' is used in the sentence. ' $B a h^{\prime}$ ' is a word from an East Malaysia's (Sabah and Sarawak) dialect. Its usage differs in their respective setting and pronunciation. Sabahans perceive ' $b a h^{\prime}$ ' as stronger than ' $l a h^{\prime}$ in terms of its emphasis, whereas in Sarawakian, 'bah' has a similar connotation with 'lah' (Lee, 2014). Occurrences of other regional dialects are also spotted alongside the intellect insult 'noob', such as Melaka (\#11866), Sabahan (\#20944), Kelantanese (\#22532), Kedahan (\#40647) and Sarawakian (\#31968).

\section{b. Use of Animal Imagery}

One important aspect that needs special attention is the use of animal imagery in degrading someone's intelligence. Although the analysis indicated that such use of animal imagery occurs rarely, it should still be emphasised in this study because most Malaysians can be easily insulted, especially when they are being called or associated with 'lembu'. Culturally, Malays consistently use the word 'lembu' (cow in English) to identify someone who is being thoughtless and dim-witted by using vulgar expressions such as 'bodoh macam lembu' (stupid like a cow). The term 'lembu' is deemed taboo by the Malays, given that it is one of the most violent and provocative words. It degrades their pride as a human being and humiliates their identities. Despite the low number of its occurrences on Twitter, tweet \#5213 reflects the genuine Malaysian online interaction that depicts the language habits of most Malaysians (specifically the Malays), which uses 'lembu' as an indication of stupidity, whereas 'lembu' in \#3444 is relatively correlated with worthlessness concept.

Table 11: Using animal imagery to insult

\begin{tabular}{|c|c|}
\hline Post no. & Tweet \\
\hline \#3444 & $\begin{array}{l}\text { 'Jadi lelaki kalau pemalas nak buat kerja, hidup setakat nak menyusahkan orang elok jadi } \\
\text { lembu ja la weh' }\end{array}$ \\
\hline \#5213 & 'Aku yang buat itu ini, kau yang ambil nama. Memang aku ni lembu ke đŸ?],', \\
\hline
\end{tabular}

In addition to being a sensitive word to the Malay community, the word 'lembu' should not be brought up in front of other races, especially the Indians because they view 'lembu' (cow) and bull as sacred-a caretaker, a maternal figure and a symbol of unselfish giving (Ismail, Noh and Omar, 2016). The indecent use of the word 'lembu' in devaluing someone's intelligence should be outlawed among the Malaysian community to respect other races (particularly the Indians) and avoid people being demeaned when compared with an animal. Such a slur is considered the lowest and the most offensive insult that a person can receive.

\section{c. Multiple Character Repetition}

The last feature is multiple character repetition. In their research, Ibrohim and Budi (2018) stated that people sometimes use abusive words by repeating some characters of the word to express their level of anger, as in \#9394. In this tweet, the person used multiple character repetition (of the letter ' $l$ ') for 'sengal' to show his/her intense annoyance over the incident. The intensity of 'sengal' is further enhanced with other abusive words like 'semak' and 'bongok' (another repetition of ' $k$ '). 


\begin{tabular}{cc} 
& Table 12: Using multiple character repetition \\
\hline Post no. & \multicolumn{1}{c}{ Tweet } \\
\hline$\# 9394$ & 'Semak, daripada 5 nak buang jadi 4 .. Pastu yg dept yg dah ada 8 org nak tmbah ke 9 \\
& .. Alaaaa bongokkk .. Dept tu buat apa je sengallIII'? \\
\hline
\end{tabular}

In summary, the use of intelligence-related insults is not only restricted to one word (single word). The insults can take many forms, including their use in phrases and clauses. Although social media users opt to use a variation of spelling for certain intelligence-related insults, other linguistics realisations, such as code-mixing, are also worth discussing.

\section{DISCUSSION}

Although social media is a central way for people to connect and maintain relationships, the level of connectivity may lead to potentially disturbing outcomes to some. Perceiving how people can be upsettingly heartless and how words can be hurtful on the Internet is implausible. However, social media is known for having a limited ability in conveying or transferring messages, given that it provides non-verbal messages and lacks vocal expression. Through online communication, we can see how social media users gradually become ruder, harsher and more difficult to control. At the same time, more people are being ridiculed and humiliated in endless ways in the cyberspace context, especially through offensive and abusive content.

The results of this study show the diversities of intelligence-related insults that are extensively used by online communities in humiliating someone's intelligence. 'Bodoh', 'bebal', 'sengal', 'gila', 'bodoh', 'bangang', 'bengap', 'semak' and 'bongok' are among the recurring words that have an intense impact in demeaning or belittling other people. Worse, the use of such terms can lead victims to experience fatal effects such as losing self-worth and committing suicide. Although Malaysians are still paying attention to being appropriate and polite in their everyday communication, the exploitation of those harsh words by thoughtless social media users is considered to violate the concept of 'budi bahasa' (person of culture), wherein emotion, politeness, and language use are among its fundamental characteristics (Romlah, 2012). Moreover, these circumstances of cyberbullying are tainting another Malaysian concept of 'saving face', wherein people start ignoring others' face with the purpose of doing something that can bring them 'malu' (shame, shyness and embarrassment) (Evason, 2016). In one way, this situation leads Malaysians to lose their cultural identity as a country that upholds the concept of 'saving face', similar to many Asian countries.

One important aspect that needs to be discussed is the linguistic features of intelligence-related insults. Given that social media users have changed their writing styles through informal language and short forms (spelling alteration), detecting abusive language in social media becomes more difficult (Ibrohim \& Budi, 2018). In relation to this argument, the findings of this study show the use of code-mixing in intelligence-related insults. The analysis indicates that irregular manifestations of code-mixing signify different degrees of stupidity, such as 'bodoh stupid'. Malaysians, especially the youth, are bilingual speakers of Malay and English. Thus, Malaysians use code-mixing or code-switching in their online communication, wherein most cases have pragmatic reasons and semantic significance (Hadei, Kumar \& Jie, 2016) serve as the bases. Other features that involve cultural elements, such as dialect interference and the use of Malaysian English emphasis markers, are also among the causes that hinder the existing abusive language filtering systems that are set by the respective social media developers. In most cases, the filtering systems only concern the 
universal language (English), explaining the ultimate reasons for newly-developed filtering systems or abusive language detection mechanisms by researchers of multilingual countries.

Another feature of intelligence-related insults worthy of discussion is the use of laughing remarks such as 'hahahaha', 'lol' and 'kahkahkah'. Although intelligence-related insults are deemed harsh and aggressive, the use of laughing remarks helps to tone down the meaning that of the insults, as shown in the following table.

Table 13: Use of laughing remarks

\begin{tabular}{cl}
\hline Post no. & Tweet \\
\hline$\# 9944$ & 'Aku dengar org sebut sin jadi sim, hahahaha noob https://t.co/9DM8JHO9ph' \\
$\# 10823$ & '@nursyzwani @zainulsedek_asal aku yang noob kalau zainul bab ejaan pun tak lepas \\
& ni hahahahahahaahaha' \\
$\# 28844$ & '@iamNickyNic So stupid omg haha benci' \\
$\# 3812$ & 'Kalau nak tahu annnnn. Aku takdelah bodoh mana đت̈ Ž. Hehehehhehee' \\
$\# 7772$ & 'Bodo la anep ni uahahahahahahahahahahahahaha' \\
\hline 3996 & 'Kah kah kah. Bengap https://t.co/q60ZPKkXV6'
\end{tabular}

Although the laughing remarks are purposely incorporated to lessen the offensive impact and used in a context in which the speaker seems to joke around, people will still get hurt by these insults given that the rudeness is pervasive. The laughing remarks provide advantages for the speaker (giving the impression that they are not using rude language), whereas it has adverse effects to the listener. An insult remains an insult regardless of how someone sugarcoats it. This act of rudeness and bullying can easily spiral and trigger further negative behaviours if not prevented.

\section{CONCLUSION}

This study demonstrates the linguistic features of insults that are related to intellect, and the most dominant feature deals with code-mixing, code-switching, dialect interference and the use of Malaysian English. Given that Malaysia is known as a multilingual country, detecting and filtering abusive language in social media is strenuous and almost impossible. The available filtering systems do not recognise local or native languages, and most automated detections of offensive text normally use natural language processing approaches that are highly reliant on the language used in the content (Pitsilis, Ramampiaro \& Langseth, 2018).

Moreover, this study utilises Twitter corpus that has been collected within one week duration. Using Twitter API and R software, the analysis is restricted in numerous aspects. Firstly, the limited data might not represent the actual frequencies of cyberbullying events on Twitter. Secondly, the language has been set to English and Malay only. In addition, the language setting constraint used might not designate the authentic cyberbullying languages in Malaysia, given that the country has other languages or dialects.

For future studies, exploring the language of cyberbullying in Malaysia should be done in a longer period of data collection. Future studies may also focus on obtaining additional local languages to analyse. Other features of intelligence-related insults that are not discussed in this study can be explored in the future. Future studies may also focus on other feature extractions such as the use of uppercase or any other perceptible characteristics that may arise from local languages, such as Chinese and Indian. 


\section{ACKNOWLEDGMENT}

The authors received financial support for the research and authorship of this article from Universiti Kebangsaan Malaysia Research Grant coded GUP-2017-079.

\section{BIODATA}

Shahidatul Maslina Mat So'od is currently pursuing her Doctor of Philosophy degree at Universiti Kebangsaan Malaysia (UKM), specialising in Language Studies. She is also a lecturer at Centre for Language Studies and Generic Development, Universiti Malaysia Kelantan (UMK).Email: maslina.ms@umk.edu.my

Tan Kim Hua is an Associate Professor at the Sustainability of Language Sciences Research Centre (SOLS), Faculty of Social Sciences and Humanities, Universiti Kebangsaan Malaysia (UKM). Her interest includes Corpus Linguistics and Language, Power and Ideology. She is the Editor-in-Chief of the 3L Journal: Language Linguistics, Literature, The Southeast Asian Journal of English Language Studies @http://ejournals.ukm.my/31. Email: kimmy@ukm.edu.my

Bahiyah Abdul Hamid is an Associate Professor at the Sustainability of Language Sciences Research Centre (SOLS), Faculty of Social Sciences and Humanities, Universiti Kebangsaan Malaysia (UKM). Her recent research studies focus on language and gender, gender issues, identity construction, code alternation and code choice, and discourse and semiotics analysis. Email: bahiyah@ukm.edu.my 


\section{REFERENCES}

Abu Bakar, H. S. (2015). The emergence themes of cyberbullying among adolescences. International Journal of Adolescence and Youth, 20(4), 393-406.

Al Garadi, M. A., Varathan, K. D., \& Ravana, S. D. (2016). Cybercrime detection in online communications: The experimental case of cyberbullying detection in the Twitter network. Computers in Human Behavior, 63, 433-443.

Ang, R. P., \& Goh, D. H. (2010). Cyberbullying among adolescents: The role of affective and cognitive empathy, and gender. Child Psychiatry \& Human Development, 41(4), 387397.

Asanan, Z. Z. T., Hussain, I. A., \& Laidey, N. M. (2017). A study on cyberbullying: Its forms, awareness and moral reasoning among youth. International Journal of Media and Communication, 1(1), 1-5.

Balakrishnan, V. (2015). Cyberbullying among young adults in Malaysia: The roles of gender, age and Internet frequency. Computers in Human Behaviour, 46, 149 - 157.

Brown, V. (2017, October 18). Cyberbullying: Words can hurt too. The Star. Retrieved from https://www.thestar.com.my/news/nation/2017/10/19/cyberbullying-words-canhurt-too/

Chasib, H. A. (2014). Exploring the effects of cyber-bullying on student's attitude in online learning: A case study of UUM (Doctoral dissertation, Universiti Utara Malaysia).

Crystal, D. (1987). The Cambridge encyclopedia of language. New York: Cambridge University Press.

Don, Z. M. (2003). Language-dialect code-switching: Kelantanese in a multilingual context. Multilingua, 22(1), 21-40. Retrieved on January 20, 2019 from https://www.academia.edu/4044405/Language-dialect_codeswitching_Kelantanese_in_a_multilingual_context

Evason, N. (2016). Malaysian culture - References. Retrieved from https://culturalatlas.sbs.com.au/malaysian-culture/malaysian-culture-references

Gan, S. S., Zhong, C., Das, S., Gan, J. S., Willis, S., \& Tully, E. (2014). The prevalence of bullying and cyberbullying in high school: A 2011 survey. Int J Adolesc Med Health, 26(1), 2731.

Ghani, N. M., \& Ghazali, S. (2015). Tindak balas pengguna YouTube terhadap kes buli dalam kalangan remaja di Malaysia. Sains Humanika, 6(1).

Guan, N. C., Kanagasundram, S., Ann, Y. H., Hui, T. L., \& Mun, T. K. (2016). Cyber bullying-a new social menace. Advisory Board, Associate Editors Associations Between Low SelfControl and Editorial Board Members iii-v And Aggression Among Malaysian Male Prisoners 79-86 Information for Authors vi, 104.

Hadei, M., Kumar, V. C., \& Jie, K. S. (2016). Social factors for code-switching: A study of Malaysian-English bilingual speakers. International Journal of Language and Linguistics, 4(3), 122-127.

Hussain, M. G., Al Mahmud, T., \& Akthar, W. (2018, December). An approach to detect abusive bangla text. In 2018 International Conference on Innovation in Engineering and Technology (ICIET) (pp. 1-5). IEEE.

Ibrohim, M. O., \& Budi, I. (2018). A dataset and preliminaries study for abusive language detection in Indonesian social media. Procedia Computer Science, 135, 222-229. 
Ismail, I. R., Noh, C. H. C., \& Omar, K. (2016). Knowing the taboos, improve intercultural communication: A study at Terengganu, east coast of Malaysia. Procedia-Social and Behavioral Sciences, 219, 359-366. Retrieved on January 18, 2019 from https://www.sciencedirect.com/science/article/pii/S1877042816300593

Kowalski, R. M., Giumetti, G. W., Schroeder, A. N., Lattanner, M. R. (2014). Bullying in the digital age: A critical review and meta-analysis of cyberbullying research among youth. Psychol Bull, 140(4), 1073-137.

Lai, C. S., Mohamad, M. M., Lee, M. F., Mohd Salleh, K., Sulaiman, N. L., \& Chang, W. V. S. (2016). Cyberbullying among youth in Malaysia. Malaysian Journal of Youth Studies, 15.

Lee, Z. E. (2015). Colloquial Malaysian English (CMalE): A problem or a cool phenomenon? Retrieved from http://repositori.uji.es/xmlui/bitstream/handle/10234/127527/TFM_Lee_Zhia_Ee.p df?sequence $=1$

Liveatpc.com. (2019, January, 31). Malaysia among top 10 Instagram users in the world. Retrieved from https://liveatpc.com/malaysia-among-top-10-instagram-users-in-theworld/

Malaymail. (2018, September 1). Legend Hawk slams Malaysian skater haters as games teen trolled.

https://www.malaymail.com/news/sports/2018/09/01/legend-hawk-slamsmalaysian-skater-haters-as-games-teen-trolled/1668370

Miller, K. (2016). Cyberbullying and its consequences: How cyberbullying is contorting the minds of victims and bullies alike, and the law's limited available redress. S. Cal. Interdisc. $L, 26,379$.

Mitchell, K. J., Ybarra, M. L., \& Korchmaros, J. D. (2014). Sexual harassment among adolescents of different sexual orientations and gender identities. Child Abuse \& Neglect, 38(2), 280-295.

Nandhini, B. S., \& Sheeba, J. I. (2015, March). Cyberbullying detection and classification using information retrieval algorithm. Proceedings of the 2015 International Conference on Advanced Research in Computer Science Engineering \& Technology (ICARCSET 2015) (pp. 1-5).

Noh, C. H. C., \& Ibrahim, M. Y. (2014). Kajian penerokaan buli siber dalam kalangan pelajar UMT. Procedia-Social and Behavioral Sciences, 134, 323-329.

Ozden, M. S., \& Icellioglu, S. (2014). The perception of cyberbullying and cybervictimization by university students in terms of their personality factors. Procedia - Social and Behavioral Sciences, 116, 4379-4383.

Pitsilis, G. K., Ramampiaro, H., \& Langseth, H. (2018). Detecting offensive language in tweets using deep learning. Applied Intelligence, 48(12), 4730-4742.

Rezvan, M., Shekarpour, S., Balasuriya, L., Thirunarayan, K., Shalin, V. L., \& Sheth, A. (2018). A quality type - Aware annotated corpus and lexicon for harassment research. Proceedings of the 10th ACM Conference on Web Science (pp. 33-36).

Romlah Ramli. (2013). Culturally appropriate communication in Malaysia: Budi bahasa as warranty component in Malaysian discourse. Journal of Multicultural Discourses, 8(1), 65 - 78. doi: 10.1080/17447143.2012.753895. 
Rosli, J. (2018, October 27). Malaysia sixth-worst in global cyber-bullying ladder, survey shows.

https://www.malaymail.com/news/malaysia/2018/10/27/malaysia-sixth-worst-inglobal-cyber-bullying-ladder/1687181

Sari, S. V., \& Camadan, F. (2016). The new face of violence tendency: Cyber bullying perpetrators and their victims. Computers in Human Behavior, 59, 317-326.

Selkie, E. M., Fales, J. L., \& Moreno, M. A. (2016). Cyberbullying prevalence among US middle and high school-aged adolescents: A systematic review and quality assessment. Journal of Adolescent Health, 58(2), 125-133.

Simon, S. (2017). Cyber victimization: School experience of Malaysian cyberbullied teenagers. International Journal of Humanities and Social Sciences, 11(3), 713-720.

Syafique, S. (2014, December 24). Cyberbullying on the rise in 2014: Who is responsible for the phenomenon?. Astro Awani. Retrieved from http://english.astroawani.com/before-2015/cyberbullying-rise-2014-whoresponsible-phenomenon-50681.

Tang, R. (2016, July 5). Cruel insults hurled at this Malaysian woman continued even after her suicide note. Retrieved from https://says.com/my/news/arlina-banana-wants-tocommit-suicide-over-cyberbullying

Telenorgroup. (2016, June 17). Telenor group supports 'stop cyberbullying day 2016' across its markets in Asia. Retrieved from https://www.telenor.com/media/pressrelease/telenor-group-supports-stop-cyberbullying-day-2016

The Star. (2018, August 30). More and more celebrities are being bullied online. Retrieved from https://www.thestar.com.my/lifestyle/people/2018/08/30/celebritycyberbullying-victims

van Geel, M., Vedder, P., Tanilon, J. (2014). Relationship between peer victimization, cyberbullying, and suicide in children and adolescents: A meta-analysis. JAMA Pediatr, 168(5), 435-44.

Yusuf, S., Hassan, M. S. H., \& Ibrahim, A. M. M. (2018). Cyberbullying among Malaysian children based on research evidence. Encyclopedia of Information Science and Technology (4th ed., pp. 1704-1722). IGI Global.

Yusuf, S., Hassan, M. S., Samah, B. A., Ibrahim, M. S., Ramli, N. S., Rahman, N. A. A., \& Osman, M. N. (2018). Parental attachment and cyberbullying experiences among Malaysian children. Pertanika Journal of Scholarly Research Reviews, 4(1). 


\section{APPENDIX}

\section{Cyberbullying Questionnaire}

Cyberbullying is when someone (typically teens), bully or harass others on social media sites. Harmful bullying behavior can include posting rumours, threats, sexual remarks, a victim's personal information, or pejorative labels (i.e., hate speech).

Please complete the following questionnaire.

Kindly tick ( / ) for your answer.

1. What is your gender?

$\square$ Male $\quad$ Female

2. How old are you?

\begin{tabular}{|l|l|}
\hline $18-20$ years old \\
$21-23$ years old \\
$24-26$ years old \\
$26+$ years old
\end{tabular}

3. Have you been bullied?

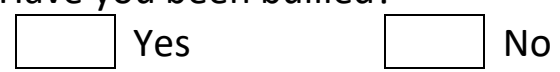

If you choose 'YES', please proceed to No $\mathbf{4}$ and 5. If 'NO', please answer NO 6 and 7.

4. If you have been bullied on the internet through text messages, what are the word(s) or sentence(s) the cyberbully sent you? (eg: stupid, you go kill yourself etc)

5. If you have been bullied on the internet through visual messages (pictures/video clips etc), what are the kinds of visual message(s) the bully sent you? (eg: your personal picture has been photo shopped unpleasantly etc).

6. If you have seen or heard of anyone being bullied on the internet, can you give some examples of those messages? It can be word(s) or sentence(s) that have been sent to him/her. 
7. If you have seen anyone being bullied on the internet through visual messages, you can describe what kind of visual messages (pictures/images/videos etc) that he/she received? (eg: someone sent a video of "slapping face" to that person/ someone sent her 'POOP' emoticons etc)

8. Have you cyberbullied other person(s)?

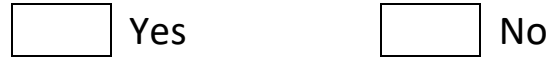

9. If yes, what are the word(s) or sentence(s) that you send to the person? (eg: $b^{* * * *}$, kau tu gila! etc)

10. If you have used visual messages, what are the types of pictures/images/videos that you send to the other person? (eg: you send him a picture of $\mathrm{F}^{* * *}$ finger etc)

End of questionnaire. Thank you. 